\title{
Pregnancy and Birth After a Two-Step PGD: Polar Body Diagnosis for Hemo- philia A and Array CGH on Trophectoderm Cells for Chromosomal Aberrations
}

\author{
Schwangerschaft und Geburt nach Zwei-Stufen-PID: Polkörperdiagnostik auf Hämophilie A und Array CGH \\ (Comparative Genomic Hybridization) an Trophektodermzellen auf chromosomale Aberrationen
}

Authors

Affiliations
W. Würfel ${ }^{1}$, R. Suttner ${ }^{1}$, D. Shakeshaft ${ }^{1}$, V. Mayer ${ }^{2}$, U. Schoen ${ }^{2}$, K. Sendelbach ${ }^{2}$, M. Locher ${ }^{2}$, U. Koehler ${ }^{2}$, K. Fiedler ${ }^{1}$, G. Krüsmann ${ }^{1}$, E. Holinski-Feder ${ }^{2}$

${ }^{1}$ KCM (Kinderwunsch Centrum München), Munich

${ }^{2}$ MGZ (Medizinisch-Genetisches Zentrum), Munich

\author{
Key words \\ - polar body diagnosis \\ - trophectoderm biopsy \\ - hemophilia A \\ - comparative genomic \\ hybridisation \\ - chromosomal aberration \\ Schlüsselwörter \\ - Polkörperdiagnostik \\ - Trophektodermbiopsie \\ - Hämophilie A \\ - $\mathrm{CGH}$ \\ - chromosomale Aberration
}

received $\quad 5.7 .2013$

revised $\quad 5.7 .2013$

accepted 16.7.2013

\section{Bibliography}

DOI http://dx.doi.org/ 10.1055/s-0033-1350705

Geburtsh Frauenheilk 2013; 73 :

812-814 @ Georg Thieme

Verlag KG Stuttgart · New York . ISSN 0016-5751

\section{Correspondence}

Prof. Wolfgang Würfel, Dr. Dr.

KCM (Kinderwunsch Centrum

München)

Lortzingstraße 26

81241 Munich

info@ivf-muenchen.de

\section{Abstract \\ v}

Objective: To demonstrate that a PGD program can be successfully established after the 2011 verdict of the German Bundestag concerning PGD. Material and Method: Eight years previously, the couple had had a daughter who suffered from clinically manifest hemophilia A due to an unbalanced X-inactivation, as well as microdeletion syndrome resulting in severe physical and mental disability. The couple wished to have a second child but refused the idea of a "trial" pregnancy. Given the indications for both, it was necessary to carry out polar body diagnosis (PBD) to rule out hemophilia A and, during the same cycle, a subsequent PGD on the blastocysts to rule out genetic aberrations. The PBD and PGD (trophectoderm biopsy, TEB) were performed after highdosage ovarian stimulation and ICSI fertilization of the oocytes. A blastocyst was successfully transferred on day 6 .

Results: The patient conceived immediately. The pregnancy developed normally and the patient gave birth to a girl in the 40th week of pregnancy. Post-natal examinations showed that the baby is free from hemophilia A and is developing normally both physically and mentally.

Conclusion: Establishment of a PGD program is now possible after legalization of PGD in Germany. It is possible to apply two investigative techniques in a single treatment cycle if multifactorial diagnosis is required.

\section{Zusammenfassung \\ $\nabla$}

Ziel: Führung des Nachweises, dass nach dem Beschluss des Deutschen Bundestags 2011 zur Präimplantationsdiagnostik (PID) diese Untersuchungstechnik erfolgreich etabliert werden kann.

Material und Methode: Das Ehepaar hatte vor 8 Jahren eine Tochter bekommen, die aufgrund einer ungleichen X-Inaktivierung klinisch manifest an einer Hämophilie A erkrankt ist. Zudem besteht eine Mikrodeletion, weswegen das Mädchen körperlich und geistig schwer behindert ist. Das Ehepaar wünschte sich ein 2. Kind, lehnte jedoch eine "Schwangerschaft auf Probe“ ab. Aufgrund der beiden Indikationen war es erforderlich, in einem einzigen Zyklus eine Polkörperdiagnostik (PKD) zum Ausschluss der Hämophilie A und nachfolgend an den Blastozysten eine PID auf genetische Aberrationen durchzuführen. Die PKD und die PID (Tropektodermbiopsie, TEB) erfolgten nach hochdosierter ovarieller Stimulation und Fertilisation der Oozyten vermittels ICSI. Es konnte eine Blastozyste am Tag 6 transferiert werden.

Ergebnisse: Die Patientin konzipierte sofort, der Schwangerschaftsverlauf war unkompliziert, ein Mädchen wurde in der 40. Schwangerschaftswoche geboren. Die Nachuntersuchungen zeigen, dass die Tochter an keiner Hämophilie A leidet und sich geistig sowie körperlich unauffällig entwickelt.

Schlussfolgerung: Die Etablierung eines PID-Programms ist nach Legalisierung der PID erfolgreich möglich. Es ist machbar, in einem Behandlungszyklus Doppeluntersuchungen durchzuführen, wenn mehrere Indikationen vorliegen. 


\section{Introduction}

\section{$\nabla$}

In Germany, key areas of reproductive medicine are governed by the Embryo Protection Act (Embryonenschutzgesetz; ESchG). Previous commentaries had raised the assumption that the Act prohibits preimplantation genetic diagnosis (PGD) of embryos. After a voluntary disclosure, the German Federal Supreme Court of Justice (Bundesgerichtshof) [1] ruled that the ESchG does not actually prohibit PGD in principle, especially not when trophectoderm biopsy (TEB) is used in which pluripotent, not totipotent cells are analysed. One year later, the German parliament (Bundestag) [5] passed a draft of the Preimplantation Diagnosis Act (Präimplantationsgesetz; PräimpG) according to which PGD is still prohibited in principle, but defining exceptions: for example, PGD may be performed in cases where genetic predisposition poses a high risk for offspring having severe disorders, or to avoid a severe damage of an embryo that is likely to result in miscarriage or stillbirth. The law came into effect in December 2011 [2].

\section{Case Report}

$\nabla$

\section{Initial clinical and legal situation}

A couple at risk of a monogenic disease and a chromosomal aberration first consulted us in 2010. Their daughter was born in 2004, she suffered from haemophilia A due to a mutation in the coagulation factor VIII (gene F8) and a non-random X-inactivation. Additionally, she showed clinical features of a 1 p36 microdeletion syndrome as a result of an unbalanced translocation which evidently occured as a germ cell mosaicism in one parent (karyotype: 46,XX,der[1]t[1;12][p36.32;p13.33]).

After extensive counselling in genetics and reproductive medicine, it became clear that the female consulter (age 32) and her husband (age 38) wished to have a second child but refused the idea of a "trial" pregnancy and were completely unwilling to raise a further child with a comparable disorder or disability for both personal and financial reasons. Given the couple's limited financial means, the couple had previously refrained from going abroad for a treatment by PGD (prohibited at that time in Germany).

At the time of diagnosis, the Preimplantation Diagnosis Act (PräimpG) had not yet been published. On the basis of the decision of the German Federal Supreme Court, it became possible to perform a PGD for a few selected cases for which a positive vote from an Ethics Committee exists. In the meantime the husband had been diagnosed several times with male subfertility, specifically with pronounced asthenozoospermia. In this case, the couple's health insurer confirmed approval of financing and the couple decided, after various renewed consultations with human genetics and reproductive medicine specialists, to seek polar body diagnosis (PBD) followed by PGD of trophectoderm (TE) cells. Sequential diagnostic procedure was necessary, because first an oocyte had to be selected not carrying the F8 gene mutation and secondly, performing PGD in order to rule out additional chromosomal anomalies (in particular an unbalanced translocation of chromosomes 1 and 12) potentially occurring in the embryo as a result of a germ cell mosaicism in the parents. The couple was informed that the necessary hormonal stimulation would be comparatively aggressive.

\section{Procedure}

After down regulation in the midluteal phase of the previous cycle (Decapeptyl $^{\circledR}$, daily $0.1 \mathrm{mg}$ s.c.), hormonal stimulation was carried out from the third day of the cycle with 200 IU recombinant human FSH (Puregon ${ }^{\circledR}$ ); ovulation was induced with 10000 HCG. Transvaginal ultrasound guided oocyte retrieval was carried out 35 hours later and yielded 17 oocytes, on 11 of which ICSI was performed according standard procedures. Biopsy of the 1st polar body (PB I) was accomplished by immobilizing the oocyte using a holding pipette to position the polar body at the 3-o'clock position. The zona then was opened using multiple laser beams (approx. $8 \mathrm{~ms}$ ) to enable the polar body to be extracted using a biopsy pipette (diameter of opening approx. 15-20 $\mu \mathrm{m}$ ). The polar body was placed into a drop of fresh culture medium and then transferred to a marked and labelled slide under the stereo microscope using a specially manufactured glass capillary. The 2nd polar bodies were removed accordingly from the 9 fertilized oocytes which showed pronuclei the next morning.

In order to identify (an) unaffected oocyte(s) without the mutated F8 allele, we established a single cell protocol for an indirect polar body diagnosis approach, based on a multiplex PCR with fluorescently labelled primers for five microsatellite markers (DXS1073, KIR3, F8C-IVS22, KIIIR, DXS1107) located close to the mutation in the F8 gene. The mutation analysis of the polar body DNA was achieved performing the first amplification steps on an AmpliGrid slide (Beckmann Coulter). Polar body diagnosis for haemophilia A resulted in the detection of two unaffected oocytes.

By day 5, two blastocysts had developed timely. Trophoblast cells were removed after the zona pellucida had been opened using a laser. A biopsy pipette was used to separate 2-6 cells from the trophectoderm extruded from the hernia; the biopsy material was placed into a drop of fresh medium and transferred under the stereo microscope into an Eppendorf tube containing $2 \mu \mathrm{l}$ phosphate buffered saline (PBS) using a glass capillary tube. The specimens were frozen at $-20^{\circ} \mathrm{C}$ until collection and Array CGH analysis. Array CGH was then performed according to the 24sure protocol (BlueGnome) using the 24sure+ chip format. Sample TE1 from blastocyst 1 revealed an aneuploid karyotype (trisomies of chromosomes 5 and 11), whereas sample TE2 from blastocyst 2 showed a euploid (or balanced) karyotype.

The couple requested the transfer of the unaffected blastocyst 2 on day 6 and refused the transfer or cryopreservation of the other blastocyst. The luteal phase was supported by the administration of progesterone $\left(3 \times 200 \mathrm{mg}\right.$ Utrogest ${ }^{\circledR}$ intravaginally). Given the high number of oocytes and development of stage I-II OHSS, we also prescribed heparine as a precautionary measure (Clexane ${ }^{\circledR}$ $201 \times 1$ s.c.).

Two weeks later, pregnancy was confirmed: HCG $294 \mathrm{mU} / \mathrm{ml}$, progesterone $220 \mathrm{ng} / \mathrm{ml}$, estradiol $714 \mathrm{pg} / \mathrm{ml}$ ). Utrogest supplements were discontinued, while injections of Clexane continued until the 12th week of pregnancy, which developed normally. Invasive prenatal diagnosis by amniocentesis in 15th week of gestation revealed normal results for F8 gene and the karyotype (female). In June 2012, the patient gave birth to a healthy girl (5.6.2012; $4280 \mathrm{~g} ; 55 \mathrm{~cm})$.

\section{Discussion \\ $\nabla$}

Polar body diagnosis (PBD) for genetic testing was first described in the 90s [17,19], our programme was established in 2003 according to the first ESHRE guidelines $[6,16]$ Preimplantation genetic diagnosis (PGD) was first described by Handyside et al. in 1989 [9]. First reports applying PGS on blastocysts were pub- 
lished from 2002 on [4,14]. Our PGS programme with trophectoderm biopsy (TEB) was introduced in 2010 [15], after the decision of the German Federal Supreme Court and according to the ESHRE guidelines [11,12].

The majority of PGD is done on day 3 embryos, however, the percentage of cycles with TEB is increasing $[7,10]$. There are only a few papers on performance of PBD and PGD in one treatment cycle $[13,18]$, usually applying on day 3 embryos. The present case, to best of our knowledge, is the first of a sequential PGD with blastocysts, in particular in Germany: a targeted molecular genetic analysis of polar bodies and an array CGH analysis after TEB.

This approach is demanding as biopsies of polar bodies and trophectoderm have to be conducted at different times. For Xlinked diseases, polar bodies can be employed to perform the mutation analysis for the monogenic disease. However, for example, in case of paternally inherited diseases, only a genetic testing of a trophectoderm sample is conductive. Then, a sequential preimplantation genetic diagnosis may be difficult to achieve due to the different diagnostic procedures for the mutation analysis and the molecular karyotyping (array CGH). To overcome this issue, a single nucleotide polymorphism (SNP)-based chip format (karyomapping) has been developed by Alan Handyside at BlueGnome, the manufacturer of the 24sure format for molecular karyotyping in PGD. This approach makes it possible to test for gene mutations and copy number variations simultaneously.

It is noteworthy to mention that the legal regulation in Germany concerning PGD is unique; both the Preimplantation Diagnosis Act and the associated regulations clearly set forth that PGD remains prohibited for totipotent embryonic blastomeres [8], which eliminates the use of day 3 blastomeres for genetic diagnosis. The position is different with respect to pluripotent trophoblast cells, which can be biopsied from the trophectoderm on day 5 after fertilisation. For this reason, in Germany, PGD can only be performed on late preimplantation embryos.

Conflicts can already be predicted for couples who call on PGD for monogenic diseases without an indication for molecular karyotyping. In these cases, only the targeted mutation analysis can be performed; trisomies and monosomies thus, escape detection. The focus of the Preimplantation Diagnosis Act undoubtedly lies on the diagnosis of monogenic disorders; however, it is important to understand that the impetus must come entirely from the couple (or the woman) involved, and may not be given by the doctor in question. In fact, the Embryo Protection Act generally focuses on the woman's freedom to choose, which means that performance of the procedures - as is, indeed, the case throughout assisted reproductive medicine in general - must be determined exclusively by the decisions of the couple (or the woman) [8].

Preimplantation genetic diagnosis for monogenic disorders is an extremely complex process and is currently performed by only very few institutions in Germany. This number should not necessarily be expected to increase significantly, especially given that the prevalence of the corresponding disorders is not rising. It may therefore be assumed that in the future preimplantation genetic diagnosis of monogenic diseases will continue to be limited to a few cooperation centers for human genetics and assisted reproductive medicine.

\section{Conflict of Interest \\ $\nabla$}

All authors declare that there is no conflict of interest.

\section{References}

1 Bundesgerichtshof(BGH). 5. StR; 2010; No. 386/09

2 Bundesgesetzblatt (BGBl) 2011; 58: 2228-2229

3 De Boer KA, Catt JW, Jansen RPS et al. Moving towards blastocyst biopsy for preimplantation diagnosis and single embryo transfer at Sidney IVF. Fertil Steril 2004; 82: 295-298

4 De Boer K, McArthur S, Murray C et al. First live birth following blastocyst biopsy and PGD analysis. Reprod Biomed Online 2002; 4: 35

5 Deutscher Bundestag 7th July 2011; No. 17/5451

6 Goosens V, Harton G, Moutou C et al. ESHRE PGD Consortium data collection IX: cycles from January to December 2006 with pregnancy follow-up October 2007. Hum Reprod 2009; 24: 1786-1791

7 Goosens V, Traeger-Synodinos J, Coonen E et al. ESHRE PGD Consortium data collection XI: cycles from January to December 2008 with pregnancy follow-up October 2009. Hum Reprod 2012; 27: 1887-1911

8 Günther HL, Taupitz J, Kaiser P. Embryonenschutzgesetz. Stuttgart, Germany: Kohlhammer; 2008

9 Handyside AH, Pattinson JK, Penketh RJA et al. Biopsy of human preimplantation embryos and sexing by DNA amplification. Lancet 1989; 1 : 347-349

10 Harper JC, Wilton L, Traeger-Synodinos J et al. The ESHRE PGD Consortium: 10 years of data collection. Hum Reprod Update 2012; 18: 234247

11 Harton G, Braude P, Lashwood A et al. ESHRE PGD consortium best practice guidelines for organization of a PGD centre for PGD/preimplantation genetic screening. Hum Reprod 2011; 26: 14-24

12 Harton GL, Magli MC, Lundin K et al. ESHRE/Embryology Special Interest Group - best practice guidelines for polar body and embryo biopsy for preimplantation genetic diagnosis/screening (PGD/PGS). Hum Reprod 2011; 26: 41-46

13 Magli NC, Gianaroli L, Ferraretti AP et al. The combination of polar body and embryo biopsy does not effect embryo viability. Hum Reprod 2004; 19: 1163-1169

14 McArthur SJ, Leigh D, Marshall JT et al. Pregnancies and live births after trophectoderm biopsy and preimplantation genetic testing. Fertil Steril 2005; 84: 1628-1636

15 Suttner R, Shakeshaft D, Koehler U et al. First experiences with PGD after trophectoderm biopsy at Kinderwunsch Centrum Munich (KCM), Germany. Reprod BioMed Online 2012; 24 (Suppl. 2): 48

16 Thornhill AR, deDie-Smulders CE, Geraedts JP et al. ESHRE PGD Consortium 'Best practice guidelines for clinical preimplantation genetic diagnosis (PGD) and preimplantation genetic screening (PGS)'. Hum Reprod 2005; 20: 35-48

17 Verlinsky Y, Cieslak J, Ivakhnenko V et al. Birth of healthy children after preimplantation diagnosis of common aneuploidies by polar body fluorescent in situ hybridization analysis. Fertil Steril 1996; 66: 126-129

18 Verlinsky Y, Cohen J, Munne S et al. Over a decade of experience with preimplantation genetic diagnosis: a multicenter report. Fertil Steril 2004; 82: 292-294

19 Verlinsky Y, Ginsberg N, Lifchez A et al. Analysis of the first polar body: preconception genetic diagnosis. Hum Reprod 1990; 5: 826-829 